$\begin{array}{ll}\text { Abstracta Iranica } & \begin{array}{l}\text { Abstracta Iranica } \\ \text { Revue bibliographique pour le domaine irano-aryen }\end{array} \\ & \text { Volume } \mathbf{2 3} \mid \mathbf{2 0 0 2} \\ & \text { Comptes rendus des publications de } \mathbf{2 0 0 0}\end{array}$

\title{
The Lie Became Great: the Forgery of Ancient Near Eastern Cultures. Groningen, 540 p., 300 pl.
}

\section{Astrid Nunn}

\section{(2) OpenEdition}

1 Journals

Édition électronique

URL : http://journals.openedition.org/abstractairanica/35214

DOI : 10.4000/abstractairanica.35214

ISSN : 1961-960X

Éditeur :

CNRS (UMR 7528 Mondes iraniens et indiens), Éditions de l'IFRI

\section{Édition imprimée}

Date de publication : 15 mai 2002

ISSN : 0240-8910

\section{Référence électronique}

Astrid Nunn, «The Lie Became Great: the Forgery of Ancient Near Eastern Cultures. Groningen, 540 p., 300 pl. », Abstracta Iranica [En ligne], Volume 23 | 2002, document 45, mis en ligne le 08 février 2010 consulté le 25 septembre 2020. URL : http://journals.openedition.org/abstractairanica/35214 ; DOI : https://doi.org/10.4000/abstractairanica.35214

Ce document a été généré automatiquement le 25 septembre 2020.

Tous droits réservés 


\title{
The Lie Became Great: the Forgery of Ancient Near Eastern Cultures. Groningen, 540 p., 300 pl.
}

\author{
Astrid Nunn
}

1 Depuis des années déjà l'auteur bataille contre la « mauvaise volonté » des scientifiques pour la reconnaissance de cette science qu'est l'identification de faux dans l'archéologie du Proche Orient ancien. Cette récente publication est quasiment un catalogue raisonné des objets que l'auteur connaît et dont il pense que ce sont des faux. Cette liste est longue d'environ 1100 objets. Avec environ 750 objets, l'Iran détient la part du lion : 116 pages y sont consacrées, contre 29 à la Mésopotamie, 21 à l'Anatolie, 13 au Levant et 1 à l'art des Scythes. Même si le nombre de pages reflète aussi les intérêts de l'auteur, la tradition de copier ou d'inventer des objets anciens semble être bien ancrée en Iran. L'art iranien est subdivisé en chapitres qui traitent successivement : Marlik/Amlach, Hasanlu, l'art achéménide (reliefs, objets métalliques, vases de pierre), l'art mède, Ziwiyé, le Luristan, Sialk, les arts élamite et sassanide. Sans entrer dans une discussion détaillée pour savoir si vraiment tous les objets présentés ici sont faux - à mon avis beaucoup le sont - l'auteur a certainement raison de dénoncer le commerce d'art international, qui, en archéologie particulièrement, enlève toute valeur historique à ces objets dont le contexte est à jamais perdu.

\section{INDEX}

Thèmes : 3.0. Généralités 


\section{AUTEURS}

\section{ASTRID NUNN}

Université de Munich (Allemagne) 